\title{
Eco friendly natural dyes
}

\author{
LATIKA SANCHIHER AND SUDHA BABEL
}

Received: 01.06.2017; Revised: 13.11.2017; Accepted: 27.11.2017

See end of the paper for authors' affiliations

\section{LATIKA SANCHIHER}

Department of Textiles and Apparel

Designing, College of Home Science,

Maharana Pratap University of

Agriculture and Technology, UDAIPUR (RAJASTHAN) INDIA
ABSTRACT : The art of dyeing with natural dyes is as old as our civilization. Dyed textile remnants found during archaeological excavations at different places all over the world provide evidence to the practice of dyeing in ancient civilizations. Dyes derived from natural materials such as plant leaves, roots, bark, insect secretions, and minerals were the only dyes available to mankind for the coloring of textiles until the discovery of the first synthetic dye in 1856 . Textiles colored with natural dyes are preferred by environmentally conscious consumers and today there is a niche market for such textiles. But the total share of natural dyes in the textile sector is very less due to certain issues involved in the production and application of these dyes. Natural dyes are sustainable as they are renewable and biodegradable but they cannot fulfill the huge demand from the textile sector.

KEY WORDS: Natural dyes, Mordants, Advantages of natural dyes

- HOW TO CITE THIS PAPER : Sanchiher, Latika and Babel, Sudha (2017). Eco friendly natural dyes. Asian J. Home Sci., 12 (2) : 631-635, DOI: 10.15740/HAS/AJHS/12.2/631-635. 